\title{
CARTILHA DO PARTICIPANTE DA REDAÇÃO DO ENEM: UMA ANÁLISE DO CONTEXTO SOCIOSSUBJETIVO E DAS CAPACIDADES DE LINGUAGEM
}

\section{BOOKLET OF THE APPLICANT ON ENEM: AN ANALYSIS OF THE SOCIO- SUBJECTIVE CONTEXT AND LANGUAGE SKILLS}

\begin{abstract}
Raniere Marques de Melo
Regina Celi Mendes Pereiraii

RESUMO: Neste artigo, objetivamos identificar e analisar a relação estabelecida entre os parâmetros do contexto sociossubjetivo e o desenvolvimento das capacidades de linguagem presentes na cartilha do participante do Exame Nacional do Ensino Médio (ENEM) 2017. Esta pesquisa documental, de abordagem qualitativo-interpretativista, fundamenta-se nas contribuições do Interacionismo Sociodiscursivo (ISD), quadro teórico-metodológico proposto por Bronckart (1999) e por pesquisadores da Universidade de Genebra. Verificamos que os objetivos da interação, presentes na cartilha, contemplam as capacidades de linguagem (discursiva e linguístico-discursiva), já que contribuem para a realização de ações, sobretudo, com implicação de mudança dessas ações de linguagem do participante-emissor; e estão materializados em sequências injuntivas.
\end{abstract}

PALAVRAS-CHAVE: Cartilha do ENEM. Contexto de produção. Capacidades de linguagem.

ABSTRACT: In this paper, we aim to identify and analyze the relationship established between the parameters of the socio-subjective context and the development of language skills present in the booklet of the participant of the National High School Exam (ENEM; Brazil's SAT), 2017. This exploratory research, guided by a qualitative-interpretative approach, is based on the contributions of socio-discursive interactionism (ISD), theoretical-methodological framework proposed by Bronckart (1999) and by University of Geneva scholars. We verified that the goals of the interaction, present in the booklet, consider the abilities of language (action, discursive and linguistic-discursive), since they contribute to the actions, especially with the implication of changing language actions on the participant-issuer; and are materialized in injunctive sequences.

KEYWORDS: ENEM's Booklet. Production context. Language skills.

Submetido em: 05 nov. 2018 Aprovado em: 06 dez. 2018

\footnotetext{
' Mestre e doutorando em Linguística pelo Programa de Pós-Graduação em Linguística da Universidade Federal da Paraíba. Grupo de Investigações Funcionalistas (GIF). E-mail: prof.ranieremarques@gmail.com.

ii Professora da Universidade Federal da Paraíba e do Programa de Pós-Graduação em Linguística (PROLING, UFPB). Doutora em Linguística pela Universidade Federal de Pernambuco. E-mail: reginacmps@gmail.com.
} 


\section{Palavras iniciais}

A proposta do MEC, a partir do intitulado Exame Nacional do Ensino Médio (MEC/INEP, 2009), configura uma política pública de reestruturação do ensino médio e utiliza esse exame como sistema seletivo de acesso ao ensino superior adotado por diversas instituições públicas no país inteiro. O exame apresenta uma metodologia ampliada para a proposta de redação ${ }^{1}$, elegendo as cinco competências expressas na matriz de referência e os níveis de conhecimento associados a elas, conforme portaria mencionada. Essa matriz de competências serve como um parâmetro de avaliação do participante, enquanto produtor de um texto dissertativo-argumentativo, no qual é necessário demonstrar uma tríplice tarefa - expor e argumentar sobre um dado tema a partir de uma situação-problema - com base nas áreas de conhecimento; e, por fim, apresentar uma proposta de intervenção que respeite os Direitos Humanos.

Com o aparente intuito de difundir e divulgar essa matriz de competências da redação entre os participantes do exame, o MEC e o Instituto Nacional de Estudos e Pesquisas Educacionais Anísio Teixeira (doravante, INEP) têm publicado, a cada ano, na internet, sob domínio público, o manual de redação do participante do ENEM, com o fito de instruir o examinando sobre o passo a passo e de apresentar dicas sobre como esse participante deve construir seu texto dissertativo-argumentativo, a partir de parametrizações de corretores especializados que atribuíram nota mil a uma coletânea de textos. Considerando os objetivos sociocomunicativos e os aspectos linguístico-estruturais da "Redação no ENEM 2017: cartilha do participante"", podemos descrevê-la como um manual, um guia para o examinando, redigido em 50 páginas compactadas em PDF, em cores preto e verde, com linguagem clara e multimodal, espacejadas com quadros e esquemas, organizadas em três grandes blocos: i) a apresentação; ii) a matriz de referência - que trata do detalhamento das cinco competências, da planificação e da organização geral do texto; e, por último, iii) a amostra de redações nota 1.000 do ENEM 2017.

\footnotetext{
1 Não vamos discutir aqui a terminologia "redação", nem mesmo questões relativas à distinção entre gênero e tipologia textuais, as quais fogem ao escopo deste artigo.

2 Escolhida, neste artigo, por ser a mais recente publicação disponível e por conter as atualizações atualmente vigentes.
} 
Essa cartilha, artefato textual de livre acesso aos interessados, cumpre fins didático-pedagógicos de orientação, de normatização e de planificação acerca de outra tipologia textual - o texto dissertativo-argumentativo. Neste artigo, tomamos como ponto de partida a reflexão sobre as condições de produção - considerando o desenvolvimento das capacidades linguageiras - que estariam contempladas no referido manual. Para desenvolver essa questão, propomo-nos a identificar e analisar a relação estabelecida entre os parâmetros do contexto sociossubjetivo e o desenvolvimento das capacidades de linguagem presentes na cartilha do participante do ENEM 2017.

Nossa análise se sustenta no arcabouço teórico do Interacionismo Sociodiscursivo (ISD), mais precisamente nas seguintes categorias analíticas e teóricos respectivos: em Bronkart (1999), os quatro parâmetros do contexto sociossubjetivo; e, em Schneuwly; Dolz (2004), o tratamento das capacidades da linguagem. Metodologicamente, este trabalho se configura como uma pesquisa bibliográfica e documental, de abordagem qualitativa.

É preciso mencionar que, embora não seja nosso interesse primário, o lugar de onde vislumbramos o objeto em análise neste artigo contempla, também, a possibilidade de entender, ainda que embrionariamente, o redimensionamento da cartilha do aluno, como dispositivo didático orientador do ensino. Trata-se de orientações oficiais parametrizadoras da redação do ENEM pretensamente destinadas à melhoria do ensino no país. Esses fatores mobilizaram nosso interesse em utilizar o referido material como fonte de pesquisa.

Além desta introdução, duas seções organizam este artigo: a primeira, que expõe e discute, brevemente, os apontamentos teóricos do ISD pertinentes a este estudo, contemplando, além de conceitos fundamentais, pontos referentes à noção de contexto sociossubjetivo e de capacidades de linguagem; e a segunda, em que desenvolvemos propriamente as análises acerca da cartilha; a elas seguem as considerações finais. 


\section{Interacionismo sociodiscursivo: breves apontamentos teóricos}

O arcabouço teórico do ISD se fundamenta em um amálgama da psicologia da linguagem e numa relação dialética com várias correntes da filosofia e das ciências humanas. Por essa razão, nos termos de Bronckart (2006, p.10), sua especificidade é "[...] postular que o problema da linguagem é absolutamente central ou decisivo para essa ciência do humano". Nesse sentido, o projeto do ISD consiste em interpretar e refletir sobre i) como o humano desempenha sua atividade social por meio da linguagem e de processos de cooperação; ii) como os agentes sociais participam no/do agir comunicativo; e iii) como essa ação de linguagem está ligada ao pensamento e à consciência. Tais princípios teóricos referem-se a um gesto de interpretação do agir comunicativo por meio das práticas linguageiras. Esse conjunto de práticas, por sua vez, materializa-se no mundo através das produções de textos verbais (oral ou escrito).

Em se tratando de produções de textos verbais, o agente-produtor mobiliza algumas representações sobre três mundos (objetivo - social subjetivo) em dois gerenciamentos diferentes: tais representações são convocadas como conteúdo temático ou referente do texto; ou essas representações são requeridas como contexto da produção textual. Este se refere à circunstância ou à conjuntura em que o agente do texto julga se encontrar e, nesse processo, os conhecimentos possibilitam um controle pragmático acerca da organização textual.

Assim, o contexto de produção, para Bronckart (2012, p.93), “[...] pode ser definido como o conjunto dos parâmetros que podem exercer uma influência sobre a forma como um texto é organizado"; contudo, essa influência, embora necessária, não é algo que se efetiva de modo mecânico. Esses parâmetros se organizam em dois conjuntos de fatores que influenciam o contexto de produção e são subdivididos a partir de duas coordenadas: (1) espaço e tempo, referente ao contexto físico, vinculados ao mundo objetivo; (2) formações social e subjetiva referentes ao contexto sociossubjetivo, cujos parâmetros pertencem aos mundos social e subjetivo. 
Esse contexto sociossubjetivo, por ora mais produtivo a nossa análise, uma vez que implica o conjunto de normas e valores e na imagem que o agente dá de si ao agir, é muito caro para a interpretação do manual em questão, pois possibilita a reflexão sobre o estatuto do enunciador e do receptor, a caracterização da posição e do lugar social, bem como sobre os objetivos empreendidos no projeto enunciativo. Ele pode ser descrito, com base em Bronckart (2012), em quatro parâmetros principais:

- o lugar social, que se reporta ao espaço (instituição) onde o texto é produzido, ou em que modo de interação foi constituído (escola, família, mídia, interação comercial, etc.);

- $\quad$ a posição social do emissor, papel social assumido que the concede o estatuto de emissor-enunciador, agente-produtor, convencionado pelo desempenho de sua função social (professor, pai, amigo etc.);

- a posição social do receptor, papel social assumido que the confere 0 estatuto de destinatário, de interlocutor, promovido pelo desempenho de sua função social (filho, aluno, criança, amigo etc.);

- o objetivo (ou os objetivos), concernente(s) ao ponto de vista do enunciador, ao efeito (ou aos efeitos) que o texto, possivelmente, gera no receptor.

É necessário entender que esses parâmetros do contexto sociossubjetivo, conforme mencionamos anteriormente, referem-se às capacidades de linguagem, aspecto que discutiremos na sequência.

O trabalho pedagógico com o gênero não pressupõe concebê-lo meramente como objeto concreto de ensino e de aprendizagem, mas, conforme Machado (2005, p. 258), "[...] como quadros da atividade social em que as ações de linguagem se realizam". Conforme essa compreensão, esse objeto concreto de ensino e de aprendizagem é definido pelas operações linguageiras que são indispensáveis para as ações referidas. Tais operações, por seu turno, formam as capacidades de linguagem. Dito de outro modo, em relação a um determinado gênero, a avaliação das capacidades linguageiras se dá na observação de como, 
nesse caso, o aluno é orientado, a partir de uma prática de linguagem, a planificar/estruturar/organizar um dado texto.

Ainda nesse sentido, segundo Dolz e Schneuwly (2004, p. 52), a noção de capacidades de linguagem faz referência às "[...] aptidões requeridas pelo aprendiz para a produção de um gênero numa situação de interação determinada", por meio de uma ação de linguagem. Essa ação linguageira consiste em produzir e interpretar um texto oral ou escrito. Tal ação resulta, por outro lado, na formação de capacidades do sujeito: "[...] adaptar-se às características do contexto e do referente (capacidades de ação), mobilizar modelos discursivos (capacidades discursivas) e dominar as operações psicolinguísticas (capacidades linguístico-discursivas)" (DOLZ; SCHNEUWLY., 2004, p. 63). Nesse sentido, elas estão vinculadas às aptidões do agente para a operacionalização da ação de linguagem, pressupondo, nesse processo, a mediação por um gênero textual.

A partir desse levantamento de conceitos, estabelecidos pelos pesquisadores do ISD, é possível sistematizar essas capacidades em três níveis: i) de ação - capacidade de o agente-produtor estabelecer representações do contexto de linguagem e/ou do conhecimento sobre o contexto comunicativo, de modo a produzir um texto mais adequado/adaptado aos parâmetros do ambiente físico, social e subjetivo; ii) discursiva - capacidade de fazer escolhas de modelos discursivos, a partir da construção de conhecimentos e de sua apresentação, especificamente relacionada à infraestrutura do texto (plano geral, tipos de discurso e sequências); e iii) linguístico-discursiva - capacidade de o agente realizar operações com recursos linguístico-discursivos, expressos por mecanismos de textualização (conexão, coesão nominal e verbal), por enunciativos (vozes e modalizações) e, também, por escolhas lexicais (DOLZ; SCHNEUWLY, 2004).

Em trabalho anterior, Dolz, Pasquier e Bronckart (1993), quando apresentam os níveis de capacidades, conceituam-nos a partir de um viés bem pragmático, senão vejamos: 
Quadro 1 - Capacidades de linguagem

\begin{tabular}{|c|c|c|}
\hline \multicolumn{3}{|c|}{ Capacidades } \\
\hline de ação & discursivas & linguístico-discursivas \\
\hline $\begin{array}{l}\text { A criança, a partir dos } \\
\text { primeiros meses de sua } \\
\text { existência, constrói, com } \\
\text { base em suas interações } \\
\text { com o meio, um conjunto de } \\
\text { capacidades comunicativas } \\
\text { (pedido, ordem, intenção, } \\
\text { etc.). Quando a linguagem } \\
\text { aparece, as formas de } \\
\text { comunicação são integradas } \\
\text { ao processo comunicativo e } \\
\text { a criança desenvolve a } \\
\text { capacidade de ação verbal } \\
\text { ou linguística. }\end{array}$ & $\begin{array}{l}\text { Como os alunos selecionam } \\
\text { um tipo de discurso para uma } \\
\text { determinada ação linguística? } \\
\text { Como eles constroem os } \\
\text { critérios que lhes permitem } \\
\text { escolher entre os modelos } \\
\text { discursivos disponíveis no } \\
\text { ambiente de linguagem? }\end{array}$ & $\begin{array}{l}\text { Contempla cinco conjuntos } \\
\text { de operações envolvidos } \\
\text { em qualquer produção de } \\
\text { linguagem: planejamento, } \\
\text { estruturação temporal, } \\
\text { coesão, conexão e } \\
\text { operações de modalização. }\end{array}$ \\
\hline
\end{tabular}

Fonte: Elaborado pelos autores a partir de Dolz, Pasquier e Bronckhart (1993, tradução nossa).

Mesmo que distintas em três níveis, essas capacidades não atuam de forma individualizada, uma vez que são ativadas numa relação de interdependência. É o gênero textual, por sua vez, o corolário dessa articulação entre os três níveis, o que resulta em uma ação linguageira situada e produtiva. Partindo desses pressupostos, demonstraremos, na seção seguinte, como se estabelece, na Cartilha do ENEM, a relação dessas capacidades com os parâmetros do contexto sociossubjetivo.

\section{Os parâmetros do contexto sociossubjetivo, as capacidades de linguagem e a cartilha do ENEM}

Nesta seção, fazemos emergir os componentes linguísticos, textuais, discursivos e contextuais que nos interessam enquanto objeto de reflexão, no material eleito para análise, levando em consideração as categorias analíticas já mencionadas e pontuando a pertinência teórica que lhe dá sustentação no domínio do ISD.

No $2^{\circ}$ bloco da cartilha do participante da redação do ENEM, aquele que explicita as cinco competências a serem exploradas, encontramos três listas de instruções, intituladas de recomendações, as quais estão presentes apenas em 
três das cinco competências. Para efeito de delimitação de dados para análise, selecionamos essas três séries de recomendações como alvo de nossa discussão, em virtude das regularidades que elas mantêm: uma voz didáticopedagógica, institucionalmente autorizada, por meio de uma tonalidade enunciativa expressa em uma dimensão pragmática, acionada por sequências injuntivas, profere ordens, orientações e sugestões direcionadas aos participantes.

$\mathrm{Na}$ seção 1.2, destinada à competência $2^{3}$, Inep (2017, p. 15-16), encontra-se a primeira ocorrência de uma lista de recomendações no manual do aluno. Apresentamos, a seguir, esta sequência de recomendações que se vincula às expectativas em relação à referida competência.

\section{Excerto 1:}

Seguem algumas recomendações para atender plenamente às expectativas em relação à Competência 2:

$\checkmark \quad$ Leia com atenção a proposta da redação e os textos motivadores, para compreender bem o que está sendo solicitado.

$\checkmark$ Evite ficar preso às ideias desenvolvidas nos textos motivadores, porque foram apresentadas apenas para despertar uma reflexão sobre o tema.

$\checkmark$ Não copie trechos dos textos motivadores. Lembre-se de que eles foram apresentados apenas para despertar seus conhecimentos sobre o tema. Além disso, a recorrência de cópia é avaliada negativamente e fará com que seu texto tenha uma pontuação mais baixa.

$\checkmark$ Reflita sobre o tema proposto para definir qual será o foco da discussão, isto é, para decidir como abordá-lo, qual será o ponto de vista adotado e como defendê-lo.

$\checkmark \quad$ Utilize informações de várias áreas do conhecimento, demonstrando que você está atualizado em relação ao que acontece no mundo. Essas informações devem ser usadas de modo produtivo no seu texto, evidenciando que elas servem a um propósito muito bem definido: ajudá-lo a validar seu ponto de vista. Isso significa que essas informações devem estar articuladas à discussão desenvolvida em sua redação. Informações soltas no texto, por mais variadas e interessantes, perdem sua relevância quando não associadas à defesa do ponto de vista desenvolvido em seu texto.

$\checkmark$ Mantenha-se dentro dos limites do tema proposto, tomando cuidado para não se afastar do seu foco. Esse é um dos principais problemas identificados nas redações. Nesse caso, duas situações podem ocorrer: fuga total ou tangenciamento ao tema.

Inicialmente, nessa primeira lista de recomendações que aparece na cartilha, o enunciador mantém uma dada uniformidade: o uso de sequências injuntivas, estrutural e linguisticamente marcadas por verbos no modo imperativo

\footnotetext{
${ }^{3}$ Compreender a proposta de redação e aplicar conceitos das várias áreas de conhecimento para desenvolver o tema, dentro dos limites estruturais do texto dissertativo-argumentativo em prosa.
} 
- Leia, Evite, Não copie, Reflita, etc. De acordo com Bronckart (1999), a opção pela sequência injuntiva corrobora o objetivo de um querer "fazer agir" do interlocutor em uma ação para o alcance do(s) objetivo(s).

Todas essas formas verbais imperativas, cotejadas semanticamente de um "dizer como fazer", possibilitam ao enunciador um contorno entoacional de caráter regular-prescritivo. Dessa maneira, o autor estrutura o texto, de forma linear e temporalmente ordenada, em uma sucessão cronológica de ações que se reportam ao atendimento da competência 2. A leitura da proposta e dos textos motivadores é indicada - Leia... - como a primeira tarefa anterior a outras. Hierarquicamente, o autor recomenda a execução de atividade por meio de sucessão lógica, recomendando ao interlocutor seguir fielmente as recomendações.

Nesse trecho, as orientações estão centradas em pelo menos três parâmetros do contexto sociossubjetivo: o papel do emissor ${ }^{4}$, nesse caso, o participante que construirá a redação; o do receptor, "o corretor", aquele que, na terceira recomendação, é responsável por atribuir uma dada "pontuação"; e os objetivos da interação (os efeitos que se quer produzir no participante-autoremissor). Esse emissor está pulverizado no texto, mas linguisticamente marcado na personalização ocorrida na passagem: "Utilize informações de várias áreas do conhecimento, demonstrando que você está atualizado em relação ao que acontece no mundo". Ou seja, nessa competência, o aluno é instruído a "fazer agir", sendo-lhe atribuído um papel relevante na interação: escritor atualizado com as notícias que acontecem no mundo. Os objetivos da interação, grifados no excerto, são materializados por meio de orações adverbias finais reduzidas de infinitivo ou de formas nominais de gerúndio - para compreender, para despertar, a validar, demonstrando etc. - que cumprem função objetivo-acional. Elas apresentam as finalidades, os efeitos, os desígnios, por meio dos quais o participante-emissor deve seguir os comandos estabelecidos.

Dessa perspectiva, percebemos que o enunciador da cartilha promove em sua atividade regular-prescritiva uma capacidade de ação da linguagem,

\footnotetext{
${ }^{4}$ Observe-se que não se trata do emissor institucional cuja voz se materializa na elaboração da cartilha, mas do examinando que construirá seu texto, assumindo esse papel e tendo em mente outro receptor, qual seja, o "corretor" da redação.
} 
quando, por meio desta, convoca uma ação linguageira, um agir-saber, de modo que o participante logre êxito no atendimento da competência 2. São, sobretudo, os objetivos dessa interação, com base no conhecimento e no contexto comunicativo, que promovem essa relação dialógica entre o contexto e a capacidade de linguagem.

A seguir, temos outro excerto do mesmo manual do INEP (2017, p. 2021), referente às recomendações para atender às expectativas em relação à Competência $3^{5}$, a da argumentação:

\section{Excerto 2:}

Seguem algumas recomendações para atender plenamente às expectativas em relação à Competência 3:

$\checkmark$ Reúna todas as ideias que the ocorrerem sobre o tema e depois selecione as que forem pertinentes para a defesa do seu ponto de vista, procurando organizá-las em uma estrutura coerente para usá-las no desenvolvimento do seu texto.

$\checkmark$ Verifique se informações, fatos, opiniões e argumentos selecionados são pertinentes para a defesa do seu ponto de vista.

$\checkmark \mathrm{Na}$ organização das ideias selecionadas para serem abordadas em seu texto, procure definir uma ordem que possibilite ao leitor acompanhar o seu raciocínio facilmente, o que significa que a progressão textual deve ser fluente e articulada com o projeto do texto.

$\checkmark$ Examine, com atenção, a introdução e a conclusão para ver se há coerência entre o início e o fim e observe se o desenvolvimento de seu texto apresenta argumentos que convergem para o ponto de vista que você está defendendo.

Como se pode perceber no trecho acima, há, também, o predomínio de sequências injuntivas marcadas pelas formas verbais imperativas, mas, sobretudo, de orientações didatizadas imiscuídas em um dado agir praxiológico. Emerge desse excerto o agir comunicativo no contexto de produção, visto que este se configura como ação linguageira que mobiliza saberes para uma referida situação concreta de produção do texto dissertativo-argumentativo.

Esses trechos evidenciam que, além da posição social do enunciador, dispersa ao longo do texto, a posição do receptor é o ponto nevrálgico para o cumprimento dessas orientações, uma vez que é esse parâmetro, também, que encaminha a produção textual. Isso é bem evidente em "[...] uma ordem que possibilite ao leitor acompanhar o seu raciocínio facilmente [...]"; assim, recai

\footnotetext{
${ }^{5}$ Selecionar, relacionar, organizar e interpretar informações, fatos, opiniões e argumentos em defesa de um ponto de vista.
} 
sobre o emissor todo o cuidado na seleção e organização de sua argumentação, a fim de que essas sejam claras ao receptor, isto é, ao corretor.

Além disso, os objetivos dessa interação, outro parâmetro do contexto, destinam-se ao participante do ENEM com um efeito de orientação acerca da infraestrutura geral do texto (BRONCKART, 2012) - do nível mais profundo e do plano geral do texto aos tipos de discursos -, perceptível nos termos "seleção", “organização", "progressão", "defesa do seu ponto de vista" além de "a introdução e a conclusão". Ademais, esse enunciador da cartilha promove duas capacidades de linguagem: a de ação e a discursiva. Essas capacidades podem ser justificadas quando o candidato é convidado a refletir sobre a infraestrutura textual do tipo dissertativo-argumentativo, mas, sobretudo, a partir dessa reflexão, a operacionalizar conhecimentos para alcançar a forma e o conteúdo que atendam à infraestrutura. Isso, em tese, resultaria em um texto em "que a progressão textual deve ser fluente e articulada com o projeto do texto", havendo "coerência entre o início e o fim", com "argumentos que convergem para o ponto de vista que você está defendendo".

Na sequência, transcrevemos, do mesmo manual do Inep (2017, p. 23), o subtópico 1.4, com recomendações da competência $4^{6}$, nos seguintes termos:

\section{Excerto 3:}

Procure utilizar as seguintes estratégias de coesão para se referir a elementos que já apareceram no texto:

a) substituição de termos ou expressões por pronomes pessoais, possessivos e demonstrativos, advérbios que indicam localização, artigos;

b) substituição de termos ou expressões por sinônimos, hipônimos, hiperônimos ou expressões resumitivas;

c) substituição de substantivos, verbos, períodos ou fragmentos do texto por conectivos ou expressões que resumam e retomem o que já foi dito; e

d) elipse ou omissão de elementos que já tenham sido citados ou que sejam facilmente identificáveis.

Resumindo: na elaboração da redação, você deve evitar:

- sequência justaposta de palavras e períodos sem articulação;

- ausência total de parágrafos na construção do texto;

- emprego de conector (preposição, conjunção, pronome relativo, alguns advérbios e locuções adverbiais) que não estabeleça relação lógica entre dois trechos do texto e prejudique a compreensão da mensagem;

- repetição ou substituição inadequada de palavras, sem se valer dos recursos oferecidos pela língua (pronome, advérbio, artigo, sinônimo).

${ }^{6}$ Demonstrar conhecimento dos mecanismos linguísticos necessários para a construção da argumentação. 
A despeito da não recorrência das formas verbais no modo imperativo, 0 que demarca uma discreta diferença em relação aos dois excertos anteriores, os tópicos são encabeçados por verbo/locução verbal ("procure" e "deve evitar") que ostentam uma ênfase de recomendação, de ordem. Embora haja a utilização de sequências injuntivas, com caráter prescritivo-normativo, o enunciador seleciona o termo "estratégias" para modalizar o tom discursivo que, nos recortes antecedentes, era explicitamente empregado como "recomendações". Assim, confere-se uma conotação menos impositiva à apresentação das "sugestões" como procedimentos ou estratégias. Tal escolha parece se associar às exigências da natureza da competência que avalia procedimentos de coesão textual.

Os procedimentos, nesse trecho, mostram-se organizados em dois blocos. No primeiro, o enunciador sugere substituições e elipse, vinculando-se às relações textuais por reiteração, por meio de recursos de substituição gramatical, lexical e retomada por elipse; no segundo, mais predominantemente, a relação textual de conexão, por meio do uso de diferentes conectores (ANTUNES, 2005).

As estratégias apresentadas nesse trecho, em suma, são pertencentes aos mecanismos de textualização, uma das camadas do folhado textual (BRONCKART, 2012). Nesse sentido, é a capacidade linguístico-discursiva, relacionada à arquitetura interna do texto, que didatiza as operações de textualização, as quais incluem os procedimentos de coesão nominal e verbal, de elipse, etc. Essa capacidade de linguagem, suscitada no contexto de produção, visa potencializar/munir o estudante/participante do ENEM quanto às astúcias para a construção de um texto dissertativo-argumentativo coeso, a partir de uma reflexão pragmática sobre o papel de elementos linguístico-discursivos. Certamente, essa capacidade de linguagem encontrada é endereçada a um dado sujeito emissor, o participante, com vistas a alguns objetivos, dentre eles, o de manter uma "relação lógica entre dois trechos do texto", para que não "prejudique a compreensão da mensagem", que terá como receptor o corretor da redação. 


\section{Considerações finais}

À guisa dessas reflexões sobre quais as condições de produção e seus reflexos, quanto ao desenvolvimento das capacidades linguageiras, que estão materializadas na Redação no ENEM 2017: cartilha do participante, encontramos, através dos parâmetros do contexto sociossubjetivo, as capacidades de linguagem sendo promovidas pelo enunciador, a fim de que os leitores da cartilha, nesse caso, os participantes do exame, sejam bem sucedidos na atividade de escrita da redação.

Com isso, percebemos que esse enunciador promove, em sua atividade regular-prescritiva, a capacidade de ação da linguagem, quando, por meio desta, convoca os candidatos a uma ação linguageira situada. Desse modo, é possível afirmar que há uma aproximação entre o agir praxiológico e as capacidades discursiva e linguístico-discursiva. Nesse manual didático-pedagógico, identificamos uma perspectiva de língua convergente ao sociointeracionismo e uma abordagem metodológica que sinaliza uma concepção de escrita constituída por atividades processuais.

Nesse sentido, no que se refere às orientações encontradas no Manual do aluno para a produção da redação do ENEM, consideramos que o sujeito produtor-enunciador mantém, através de sequências injuntivas, um evidente empenho em indicar aos candidatos caminhos metodológicos que thes proporcionem uma prática de escrita significativa.

Por fim, as análises nos mostraram, ainda que embrionariamente, que os objetivos da interação presentes na referida cartilha estão materializados em sequências injuntivas, sinalizando o que é desejável ou necessário, ligando-se às capacidades de linguagem, uma vez que contribuem para a realização de ações, sobretudo, com implicação de mudança dessas ações emanadas pelo emissor.

\section{Referências}

ADAM, J. M. Tipos de sequências textuais elementares. Tradução: Alexânia Ripoll et al. Revisão: Leci Borges Barbisan. Porto Alegre: Polígrafo, 1992. 
ANTUNES, Irandé. Lutar com palavras: coesão e coerência. São Paulo:

Parábola, 2005.

BRASIL. Ministério da Educação. Instituto Nacional de Estudos e Pesquisas Educacionais Anísio Teixeira. Diretoria de Avaliação da Educação Básica. Redação no ENEM 2017. Cartilha do Participante. Brasília, DF: MEC/DAEB, 2017.

BRONCKART, Jean-Paul. Atividade de linguagem, textos e discursos: por um interacionismo sociodiscursivo. 2. ed. São Paulo: Educ, 2012.

DOLZ-MESTRE, Joaquim; PASQUIER, A., BRONCKART, Jean-Paul. L'acquisition des discours: émergence d'une compétence ou apprentissage de capacités langagières diverses? Études de linguistique appliquée, Paris, n. 92, p. 23-37, 1993.

INEP. Portaria n. 109, de 27 de maio de 2009. 2009. Disponível em: http://download.inep.gov.br/educacao_basica/enem/legislacao/2009/portaria_en em_2009_1.pdf. Acesso em: 17 jul. 2018.

ROSA, A. L. T. No comando, a sequência injuntiva! In: DIONÍSIO, A. P.; BEZERRA, N. S. Tecendo textos, construindo experiências. Rio de Janeiro: Lucerna, 2003.

SCHNEUWLY, B.; DOLZ, J. Os gêneros escolares: das práticas de linguagem aos objetos de ensino. In: SCHNEUWLY, B.; DOLZ, J. (org.). Gêneros orais e escritos na escola. Campinas: Mercado de Letras, 2004. 